\title{
Factor Analysis to Form Customer Satisfaction on Building Material Retail
}

\author{
Alvin Livano ${ }^{1}$, Eric Harianto ${ }^{2}$ \\ School Of Business and Management, Universitas Ciputra, Citraland CBD Boulevard, \\ Surabaya, Indonesia - 602198 \\ alvin.livano@ciputra.ac.id, \\ eric.harianto@ciputra.ac.id \\ https://doi.org/10.37715/rmbe.v1i1.1947.g1549
}

\begin{abstract}
This study aims to determine the factors that shape consumer satisfaction that focuses on retailed building materials. In this study, the case raised is based on retail business UD Semeru (UDS) in Surabaya. There are $\mathbf{2 7}$ variables used as factors that are assumed to form consumer satisfaction. The results of this study will be used by UDS to develop a strategic framework that shapes the success of UDS. This research will be based on quantitative research, and uses 71 people as samples. The analytical method that is used is exploratory factor analysis (EFA) by interpreting the data in SPSS application. The results of this study show that tangible factors are the main factor that forms UDS's customer satisfaction, and the intangible factors show a supporting factor that forms UDS customer satisfaction.
\end{abstract}

\section{Keywords-Consumer Satisfaction, Quantitative, Exploratory Factor Analysis, Tangible, Intangible}

\section{Introduction}

The structure of the Indonesian economy has experienced major changes in the last few decades, from being initially oriented towards agriculture through the development of rural areas, to now being directed towards developing the service sector which concentrates in urban areas. As a result, significant urbanization of the urban areas occurs in Indonesia due to the increase in formal and informal employment (Kementerian PPN/Bappenas, 2018). In addition, the need for infrastructure and housing development in urban areas due to urbanization is also increasing (World Bank, 2016). The city of Surabaya is the second-largest city in Indonesia and it is the economic centre of East Java. Infrastructure development in this city has continued to increase over the past 10 years, especially to meet the needs to construct public roads, office buildings, schools, and housing.

The increased development in urban areas has encouraged opportunities in starting businesses that offer a wide range of building material products needed for construction, renovation and daily needs, one of which is UDS. The company was founded in 2009 and has an office at Jalan Raya Lontar No.15, Lontar, Sambikerep, Surabaya City. UDS offers product ranging from powder products sold per sack (cement, acian, plaster, cornice, calcium and talc), construction products (sand, iron and steel), up to boards (plywood, GRC, gypsum).

Figure 1. UD Semeru's Revenue in 2020

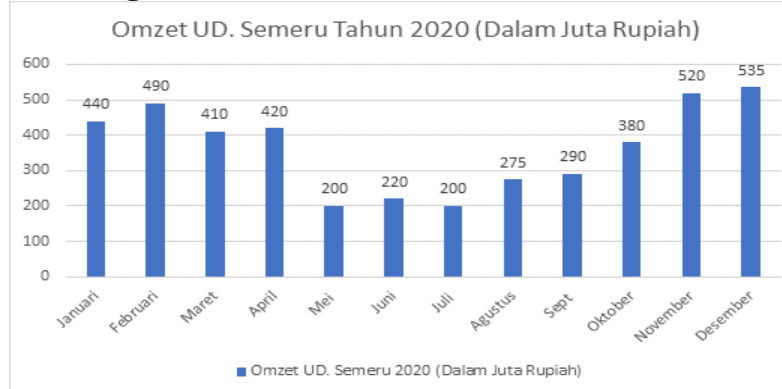

In 2020 there was a fluctuation in the income received in UDS as shown in Figure 1. The total revenue of UDS reached Rp. 4,380,000,000. The highest income of UDS in 2020 is Rp. 535,000,000 which occurred in December, while the lowest income occurred in May, with Rp. 200,000,000. Based on this data, this shows a decrease in the revenue by $18 \%$ when compared to 2019 's revenue which is $5,320,000,000$. 
Figure 2. UD Semeru's Project in 2020

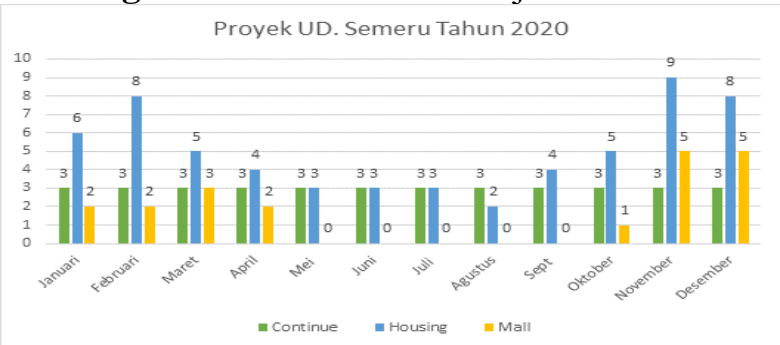

Figure 2 shows that UDS was only able to get 2 until 4 new housing projects from May to September 2020. On top of that, UDS also did not get any new shopping centre project in that particular period. A decline in sales from May to September 2020 occurs mostly because the company wasn't able to achieve its target sales, particularly in the construction of the housing project and the shopping centre project in those periods.

These encourage UDS to conduct a consumer satisfaction survey. The consumer satisfaction survey is one of the most effective measuring tools to monitor the level of customer satisfaction. This survey can be carried out regularly, involving all consumers so that the company can find out which indicators show satisfaction or dissatisfaction of their consumers (Tjiptono, 2019). By knowing the indicators that show satisfaction and dissatisfaction, it is expected that this sudden drop in its revenue will no longer occur.

\section{Literature Review}

2.1 Previous research

Some of the previous studies that were used as the base of this study are as follows:

Tabel 1. Previous Research and its Result

\begin{tabular}{|c|c|}
\hline Previous Reseach & Research Result \\
\hline 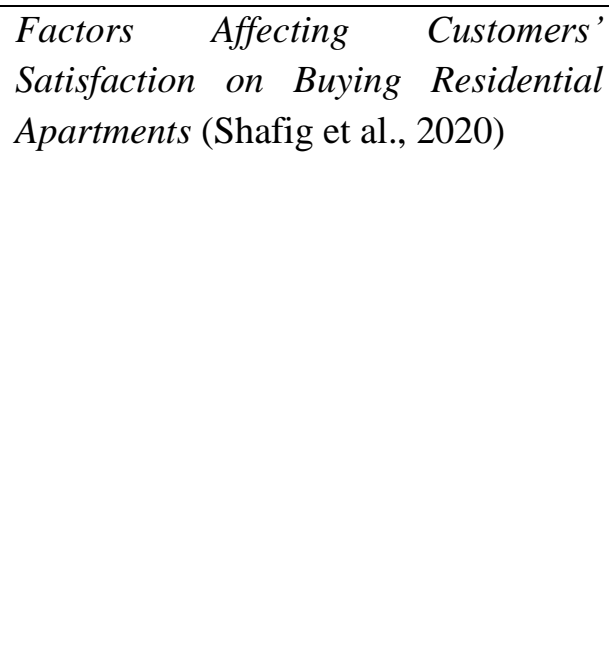 & $\begin{array}{l}\text { A positive impact on every } \\
\text { improvement of indoor (painting, } \\
\text { balcony, central heating, metal } \\
\text { shielding for windows, ventilation, } \\
\text { humidity, insulation and kitchen) and } \\
\text { outdoor (price, location, parking, } \\
\text { entrance, intercom, aesthetic } \\
\text { appearance, telecommunications } \\
\text { coverage, shops, guards, water tanks, } \\
\text { population density, street lighting, } \\
\text { billboards, trash cans, and elevators) } \\
\text { will increase the purchase demand for } \\
\text { residential apartment customer. }\end{array}$ \\
\hline $\begin{array}{l}\text { Investigation of Factors Affecting } \\
\text { Customers' Satisfaction in The } \\
\text { Supermarket Sector In Ho Chi Minh } \\
\text { City (Hcmc)-Vietnam (Tuan \& } \\
\text { Rajagopal, 2018) }\end{array}$ & $\begin{array}{l}\text { Factors that affect the customer } \\
\text { satisfaction rate in order are as } \\
\text { follows; Price, Service Quality, } \\
\text { Product Quality, and lastly Brand } \\
\text { Image }\end{array}$ \\
\hline $\begin{array}{l}\text { Factors Affecting Customer } \\
\text { Satisfaction and Customer Loyalty: } \\
\text { The Case of Binh Duong Ceramic } \\
\text { Product (Duy \& Hoang, 2017) }\end{array}$ & $\begin{array}{l}\text { Customer satisfaction and switching } \\
\text { costs have a positive effect on } \\
\text { customer loyalty. Price, Service } \\
\text { Quality, Product Quality have a } \\
\text { positive effect on consumer }\end{array}$ \\
\hline
\end{tabular}




\begin{tabular}{|c|c|}
\hline & $\begin{array}{l}\text { satisfaction. Consequently Price, } \\
\text { Quality Service, Quality Products } \\
\text { indirect impact customer loyalty. }\end{array}$ \\
\hline \begin{tabular}{lrr} 
Factors Affecting & \multicolumn{2}{r}{ Customer } \\
Satisfaction and & Behavioral \\
Intentions In Using & Mobile \\
Telecommuniations $\quad$ Service in & in \\
Bangkok, Thailand (Lin, 2012)
\end{tabular} & $\begin{array}{l}\text { Elements of the marketing mix play } \\
\text { an important role in shaping customer } \\
\text { satisfaction. Especially product, } \\
\text { process, and physical evidence. }\end{array}$ \\
\hline $\begin{array}{l}\text { Factors Affecting Customers } \\
\text { Satisfaction in Restaurants Industry } \\
\text { in Pakistan (Sabir et al., 2014) }\end{array}$ & $\begin{array}{l}\text { Price, service quality and its } \\
\text { environment have a positive and } \\
\text { significant relationship to customer } \\
\text { satisfaction. }\end{array}$ \\
\hline
\end{tabular}

The previous study found that elements of the Marketing Mix and Branding plays an important role in shaping the customer satisfaction.

\subsection{Customer Satisfaction}

Consumer satisfaction is the extent to which the performance of a product matches consumer expectations. If the product's performance far off expectations, consumers are dissatisfied. If performance matches expectations, consumers are satisfied. If performance exceeds expectations, consumers are very satisfied (Kotler \& Armstrong, 2015). Consumer satisfaction is very important for companies that not only emphasize product quality but also prioritize quality services because consumers cannot test or try the products or services before the transaction, so consumers rely on information from other parties (Brazyte et al., 2017). As consumer satisfaction is the main indicator of company performance that defines the overall experience of consumption and purchases made by consumers, this makes the variable customer satisfaction the grand theory of this research. Grand Theory is the highest abstract form of a theory composed of concepts that can be prioritized over being able to understand the social world (Mills, 2000).

\subsection{Marketing Mix}

The Marketing mix is a set of marketing tools that companies use to control and generate the desired response from their target market. This strategy includes everything a company can that influence the product demand it offers. Tangible products traditionally use the 4P model, then observing the most development of the services offered in it. In Kotler \& Armstrong (2015), Boom \& Bitner developed the concept of marketing mix into a service marketing mix or known as $7 \mathrm{P}$ (product, price, place, promotion, people, process, and physical evidence). It is considered an important strategy for business success. However, the selection of an effective strategy requires businessman to know the various alternative strategies available, including understanding how these strategies can work well in growing business conditions and its organizational environment (Khatab et al., 2019).

\subsection{Brand}

Brand has a very important role in marketing as it is the company's asset that creates value for customers by increasing their satisfaction and appreciation towards quality (Başer et al., 2016). Brand is strongly influenced by the perception of consumers. According to Keller (1993), the perception of a brand can be influenced by the perspective of individual consumers. This concept is hereinafter referred to as customer-based brand equity. Customer-based brand equity is the different impact that customers have on a brand based on how the brand is marketed. A brand is said to be positive if customers react better to the brand's marketing mix compared to other brands. Brand aspects used in this research are Brand Experience and Brand Attitude.

\subsubsection{Brand Experience}


Brand experience is conceptualized as subjective responses, internal consumers (sensations, feelings, and cognitions) up to behavioural responses evoked by brand-related stimuli that are part of brand design and identity, packaging, communication, and the environment (Carrizo-Moreira et al., 2017). Brand experience includes at least three main dimensions that are interrelated with each other, namely: Sensory dimension related to sensory and aesthetic qualities, based on the five senses, affective dimension refers to customer feelings and emotions about a brand, such as pleasure, joy, pride, nostalgia. or frustration, lastly the behavioural dimension refers to physical actions, or bodily experiences (Brakus et al., 2009).

\subsubsection{Brand Attitude}

Brand attitude is the opinion and evaluation of consumers towards a brand, related to its quality, credibility, uniqueness and feasibility to enter into consumer considerations (Ko \& Chiu, 2008). Brand attitude is a consumer's evaluation of a brand as a consumer's reaction to an object, brand association, where the result can be a feeling of liking or disliking the brand. The positive attitude of consumers towards the brand will allow consumers to purchase. On the other hand, a negative attitude towards the brand will prevent consumers from purchasing (Shin et al., 2014). Consumer attitudes towards the brand are influenced by physical and non-physical factors of the brand. Physical factors that influence consumer behaviour towards brands include support, while non-physical factors include likes and feelings of comfort that consumers feel when interacting with brand (Wu \& Lo, 2009).

\section{Research Methods}

This study is based on quantitative research, a study that is based on "a true event that occurs, that is used for research on a particular research or sample, the sampling technique is generally taken randomly, data collection uses research instruments, data analysis is set to be quantitative or statical to test the established hypothesis [20]. Exploratory Factor Analysis is used as the data analysis method. The EFA method is an independent technique that is used to explain the relation or its colouration between variants interdependent indicator that is observed. Therefore, the EFA approach is carried out to find several indicators that make up common factors without any previous theoretical basis, to build a theory (Widarjono, 2015). The application used in this method is SPSS 20.

This research was conducted at UDS. The study was conducted from January to February 2021. The population in this study were UDS consumers in Surabaya with a large classification of customers, customers with purchases above Rp. 500,000 for a single transaction with 5 repetitions of purchases within 3 months. According to the result, in 2020 there were 86 buyers belonging to the large classification customer. Calculation of the sample that will be used in this study will use the Slovin approach (Hair et al., 2014), namely:

$$
n=\frac{N}{1+N e^{2}}
$$

Where the sample member ( $\mathrm{n}$ ) is divided between the number of population members $(\mathrm{N})$ added by " 1 " and squared off the population with an error rate $(5 \%)$ so that the sample is obtained as much as:

$$
\begin{aligned}
& n=\frac{86}{1+86 \cdot 0,05^{2}} \\
& n=70,78
\end{aligned}
$$

The samples obtained were 70.78 which equivalent to 71 people. The sampling technique used is a non-probability sampling technique with a purposive sampling approach, a technique of determining the sample with certain considerations (Widarjono, 2015). The following are the sample criteria set in this study:

1. Male and female gender.

2. Minimum age of 17 years.

3. High school as its last education. 
4. Have purchased at UDS minimum 5x purchases within 3 months with a minimum nominal of IDR 500,000 in 2020.

5. Doesn't include credit customers.

A sample of $63.4 \%$ male (45 people) and $36.6 \%$ female (26 people) with an age distribution of 5.6\% aged 17-22 years (4 people), $15.5 \%$ aged 23-28 (11 people), 35.2\% aged 29-34 (25 people), 40.8\% aged 35-40 years (29 people), and $2.8 \%$ of other consumers aged $>41$ years ( 2 person) is obtained by using the criteria.

The data collection method used a questionnaire using a Likert scale, by using rating or ranking between 1-5 (from strongly disagree to strongly agree). Below is a table of the variables used as well as their definition

Tabel 2. Variabel and its defination

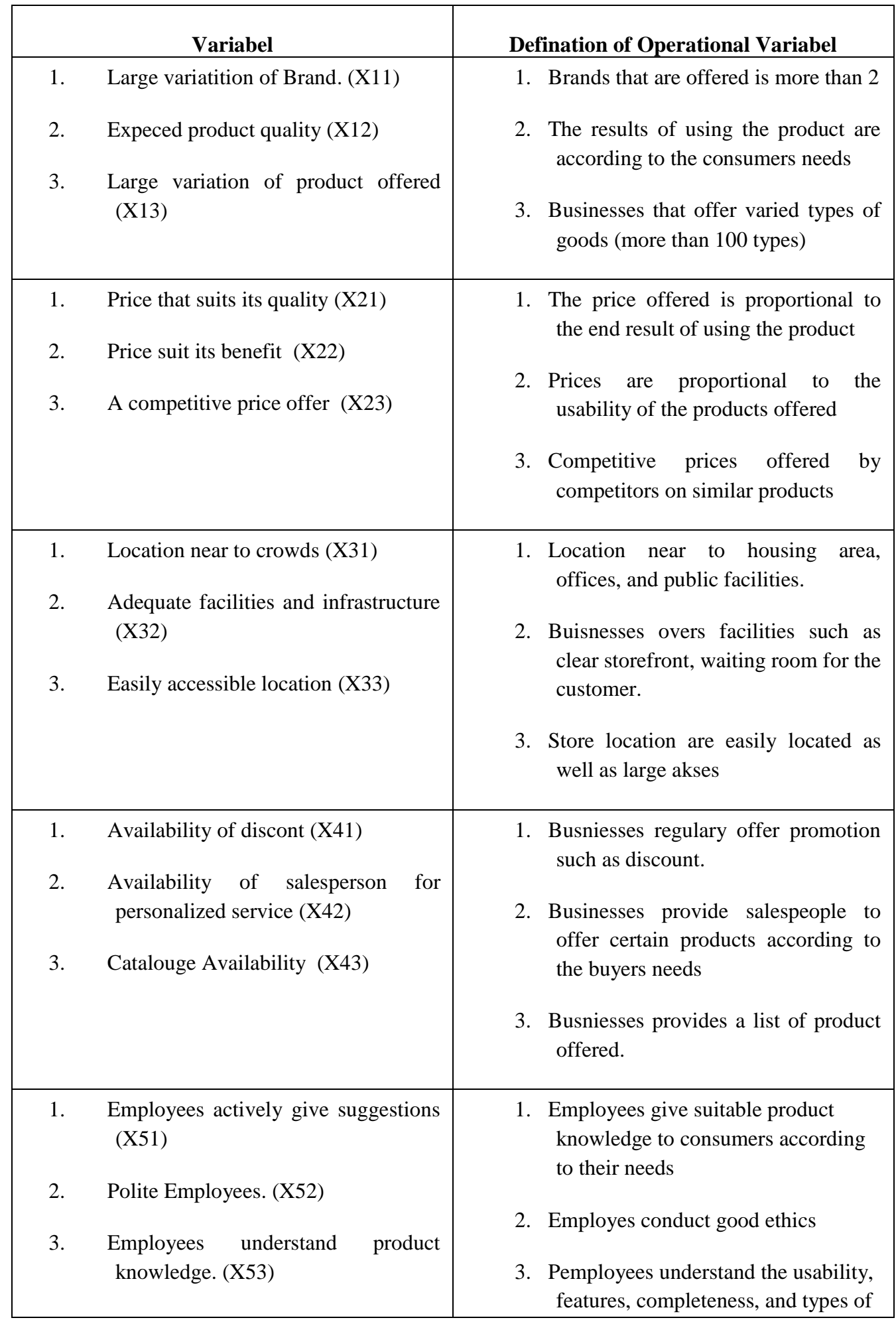




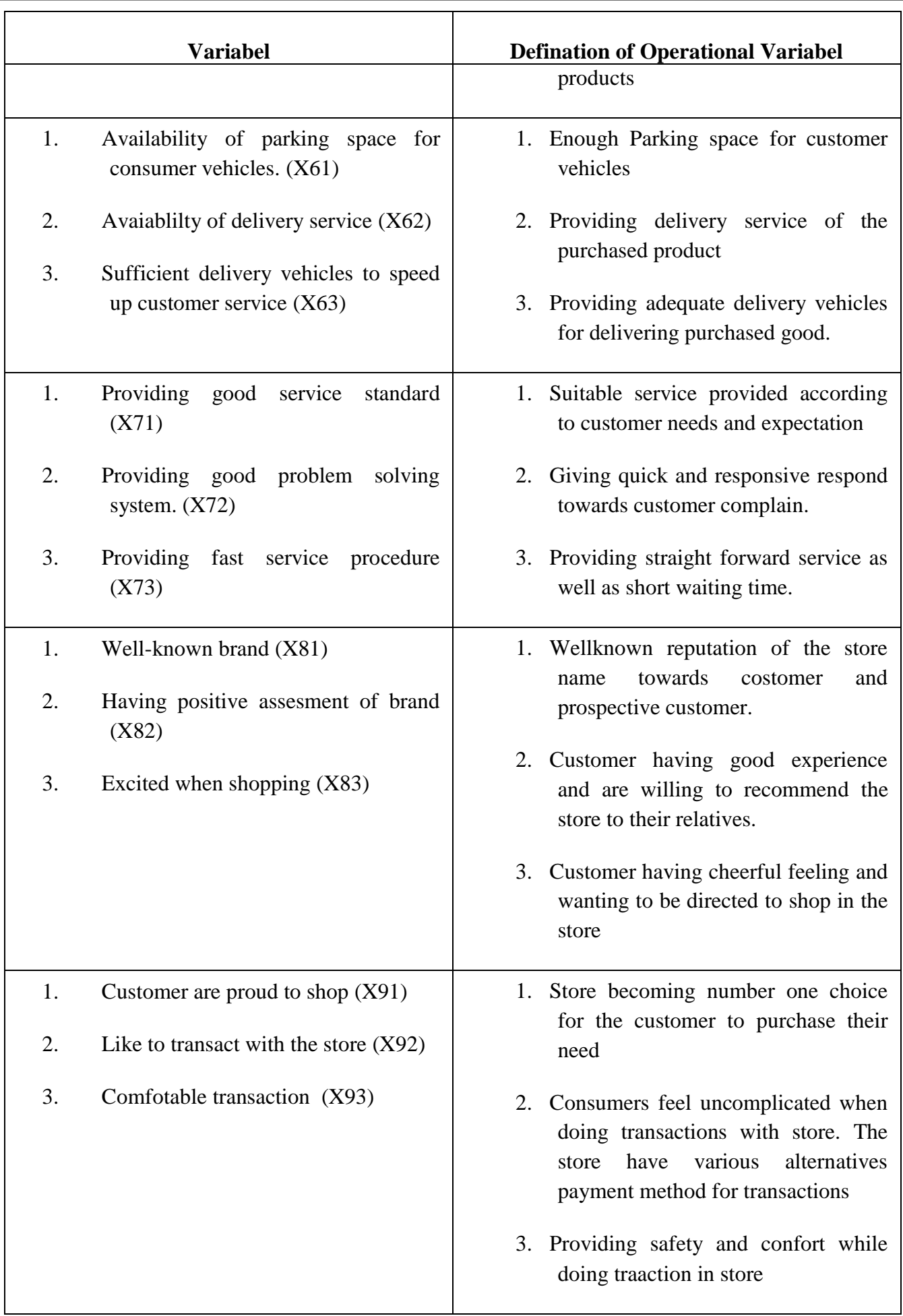

\subsection{Model Analysis}

Figure 3. Model Analysis

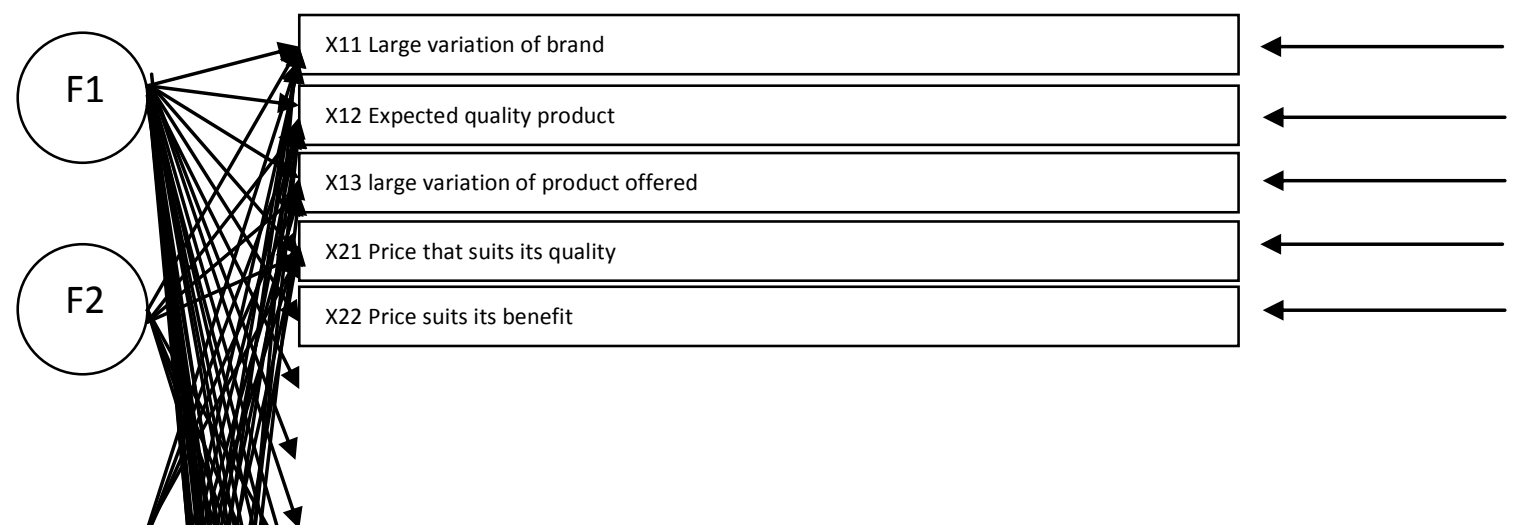




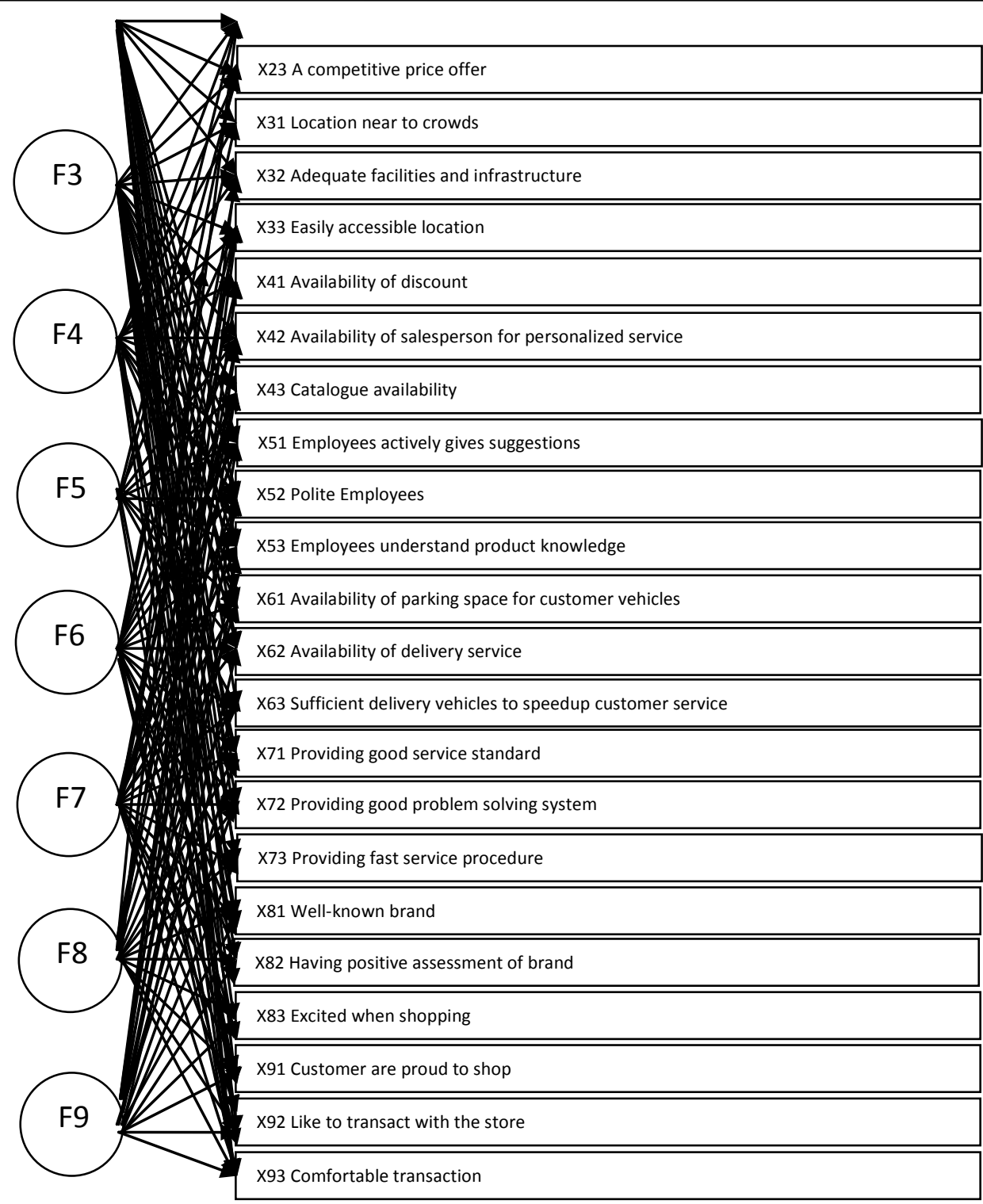

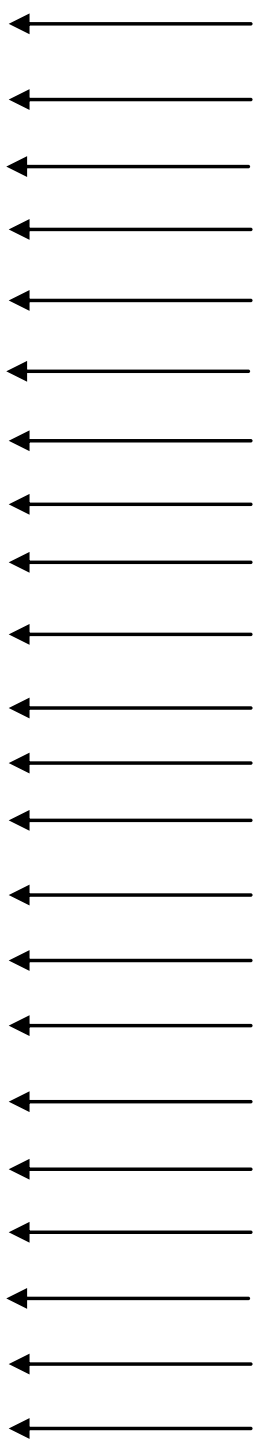

According to Hair et al ( $\mathrm{Jr}$ et al., 2010), in exploratory research, it is not known beforehand how many factors will be formed. However, for practical reasons, it can be assumed that 2-3 variables form a factor, so assumed that 9 factors will be formed. In the figure, the box represents the variable to be studied, the circle represents the factor, the arrow represents the loading factor, and the free arrow represents the error variance.

\section{Result and Discussion}

\subsection{Normality test}

According to Nasrum (2018), the instrument used in the normality test is to determine whether the instrument data were normally distributed or not. The study uses Kolomogorov-Smirnov method. In this method, the data is normally distributed if it has a Sig Value value greater than the significance of 0.05 .

Tabel 3. Normality test result 


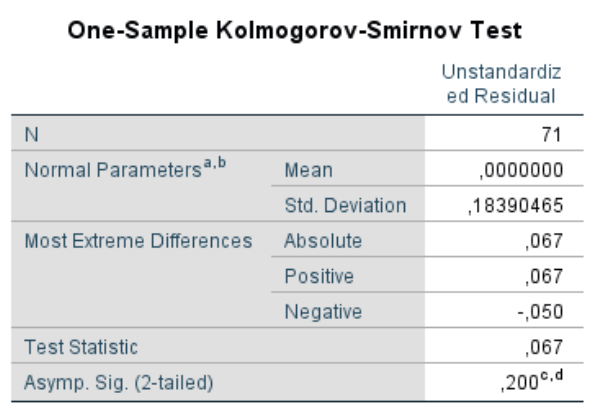

Based on Table 3, it shows that the Sig Value value is 0.200 which is greater than 0.05 , that means the data is normally distributed.

\subsection{Validity and realibility test}

According to Sugiono (2014), the instrument validity test is used to "measure the legitimacy or validity of a questionnaire, where if the Pearson correlation significance is $>0.05$, it can be concluded that the instrument item is invalid, so it must be corrected or discarded." On the other hand, all instruments are declared reliable "if the Cronbach alpha reliability coefficient has a minimum value of 0.6."

Tabel 4. Validity and realibility test

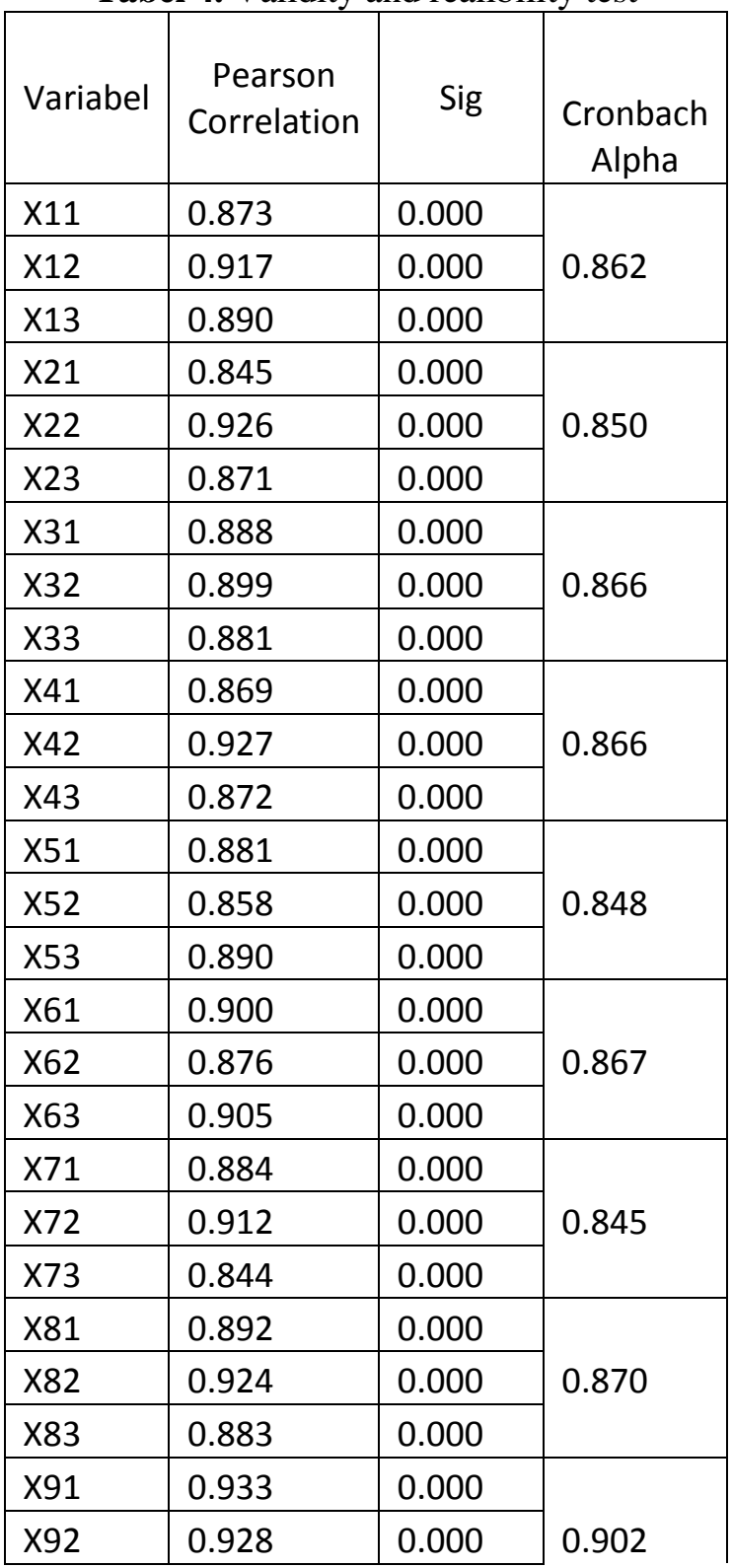




\begin{tabular}{|l|l|l|l}
$X 93$ & 0.896 & 0.000 & \\
\hline
\end{tabular}

Table 4 shows all items have a Pearson Correlation significance value below 0.05 and a Cronbach Alpha value above 0.600 , this means all items tested are valid and reliable.

\subsection{Indicator Correlation}

The data adequacy is calculated from the correlation between indicators by using the KMO method which is used to determine "homogeneity of indicators, with a minimum limit of KMO values $>0.50$ can still be accommodated for determining factor analysis, as long as the significance of Bartlett's Test Sphericity is still on the threshold < 0.05 " In this case, Widardjono (2015) continues that information in selecting appropriate indicators in factor analysis is available in anti-image metrics, where "indicators that have an MSA value $<0.5$ must be excluded from the model."

Tabel 5. KMO and Bartlett Test Sphrecity

KMO and Bartlett's Test

\begin{tabular}{|ll|r|}
\hline Kaiser-Meyer-Olkin Measure of Sampling Adequacy. &, 903 \\
Bartlett's Test of Sphericity $\quad$ Approx. Chi-Square & 1979,604 \\
& df & 351 \\
Sig. &, 000 \\
\hline
\end{tabular}

Tabel 6. Anti Image Matrix value

\begin{tabular}{|l|r|}
\hline Indikator & Nilai Anti Image Matrice \\
\hline$X_{11}$ & 0,836 \\
\hline$X_{12}$ & 0,897 \\
\hline$X_{13}$ & 0,926 \\
\hline$X_{21}$ & 0,940 \\
\hline$X_{22}$ & 0,916 \\
\hline$X_{23}$ & 0,938 \\
\hline$X_{31}$ & 0,896 \\
\hline$X_{32}$ & 0,895 \\
\hline$X_{33}$ & 0,930 \\
\hline$X_{41}$ & 0,911 \\
\hline$X_{42}$ & 0,936 \\
\hline$X_{43}$ & 0,939 \\
\hline$X_{51}$ & 0,953 \\
\hline$X_{52}$ & 0,941 \\
\hline$X_{53}$ & 0,902 \\
\hline$X_{61}$ & 0,951 \\
\hline$X_{62}$ & 0,930 \\
\hline$X_{63}$ & 0,892 \\
\hline$X_{71}$ & 0,841 \\
\hline$X_{72}$ & 0,913 \\
\hline$X_{73}$ & 0,800 \\
\hline$X_{81}$ & 0,916 \\
\hline$X_{82}$ & 0,856 \\
\hline$X_{83}$ & 0,850 \\
\hline$X_{91}$ & 0,850 \\
\hline$X_{92}$ & 0,859 \\
\hline$X_{93}$ & 0,856 \\
\hline & \\
\hline
\end{tabular}

Table 5 and 6 shows, that the KMO-MSA obtained by the model is 0.903 and is significant at an error level of $0.000<0.05$. KMO-MSA value greater than 0.50 indicates that the number of samples is sufficient. The antiimage metric value of all variables between 0.800 to 0.951 (more than 0.500 ) indicates that all of these factors deserve to be analyzed further without omitting any factor.

\subsection{Factor Extraction}

According to Widarjono (2015) Factor extraction is a mothod used to "reduce data from several indicators to produce fewer factors that can explain the correlation between the observed indicators. Factor extraction values > 0.50 indicate that these factors can explain the variables studied," and "the eigenvalues can also be used to determine the number of factors that can be formed from independent variables based on the explanatory factor variance values." Provided it has a value greater than 1. 
Tabel 7. Factor Extraction

\begin{tabular}{|c|c|c|c|c|c|c|c|c|}
\hline \multirow{2}{*}{ Component } & \multicolumn{2}{|c|}{ Communalities } & \multicolumn{3}{|c|}{ Initial Eigenvalues } & \multicolumn{3}{|c|}{$\begin{array}{c}\text { Extraction Sums of Sqr } \\
\text { Loading }\end{array}$} \\
\hline & Initials & Extraction & Total & $\% \operatorname{Var}$ & $\%$ Cum & Total & $\%$ Var & $\%$ Cum \\
\hline 1 & 1,000 & 0,626 & 12,991 & 48,116 & 48,116 & 12,991 & 48,116 & 48,116 \\
\hline 2 & 1,000 & 0,681 & 6,396 & 23,688 & 71,804 & 6,396 & 23,688 & 71,804 \\
\hline 3 & 1,000 & 0,706 & 0,974 & 3,609 & 75,413 & & & \\
\hline 4 & 1,000 & 0,673 & 0,765 & 2,833 & 78,246 & & & \\
\hline 5 & 1,000 & 0,748 & 0,638 & 2,361 & 80,608 & & & \\
\hline 6 & 1,000 & 0,624 & 0,584 & 2,163 & 82,771 & & & \\
\hline 7 & 1,000 & 0,681 & 0,480 & 1,779 & 84,551 & & & \\
\hline 8 & 1,000 & 0,744 & 0,431 & 1,597 & 86,147 & & & \\
\hline 9 & 1,000 & 0,761 & 0,398 & 1,475 & 87,622 & & & \\
\hline 10 & 1,000 & 0,741 & 0,376 & 1,392 & 89,014 & & & \\
\hline 11 & 1,000 & 0,767 & 0,361 & 1,336 & 90,349 & & & \\
\hline 12 & 1,000 & 0,714 & 0,300 & 1,110 & 91,459 & & & \\
\hline 13 & 1,000 & 0,723 & 0,287 & 1,062 & 92,521 & & & \\
\hline 14 & 1,000 & 0,597 & 0,277 & 1,024 & 93,545 & & & \\
\hline 15 & 1,000 & 0,620 & 0,253 & 0,937 & 94,483 & & & \\
\hline 16 & 1,000 & 0,711 & 0,229 & 0,846 & 95,329 & & & \\
\hline 17 & 1,000 & 0,760 & 0,204 & 0,756 & 96,085 & & & \\
\hline 18 & 1,000 & 0,658 & 0,186 & 0,690 & 96,775 & & & \\
\hline 19 & 1,000 & 0,739 & 0,160 & 0,593 & 97,368 & & & \\
\hline 20 & 1,000 & 0,785 & 0,139 & 0,514 & 97,882 & & & \\
\hline 21 & 1,000 & 0,653 & 0,119 & 0,439 & 98,321 & & & \\
\hline 22 & 1,000 & 0,710 & 0,109 & 0,403 & 98,724 & & & \\
\hline 23 & 1,000 & 0,829 & 0,095 & 0,353 & 99,077 & & & \\
\hline 24 & 1,000 & 0,778 & 0,080 & 0,295 & 99,371 & & & \\
\hline 25 & 1,000 & 0,809 & 0,068 & 0,252 & 99,624 & & & \\
\hline 26 & 1,000 & 0,802 & 0,052 & 0,193 & 99,817 & & & \\
\hline 27 & 1,000 & 0,746 & 0,050 & 0,183 & 100 & & & \\
\hline
\end{tabular}


The results of communality in Table 7 show that the value of factor extraction is range between 0.597 to 0.829 (> 0.500 ), indicating that all grains are proven to be forming factors. Based on the eigenvalues, there are 2 eigenvalues more than 1 so it can be concluded that there are 2 factors formed.

\subsection{Factor Rotation}

Factor rotation is a necessary method to produce clearer principal factors" it is used to "obtain a simpler factor structure for easier interpretation" (Widarjono, 2015). The factor rotation used in this study is Varimax factor rotation.

Tabel 8. Factor Rotation

Rotated Component Matrix ${ }^{\mathrm{a}}$

\begin{tabular}{|l|c|c|}
\hline \multirow{2}{*}{} & \multicolumn{2}{|c|}{ Component } \\
\cline { 2 - 3 } X11 & \multicolumn{1}{|c|}{2} \\
X12 & $\mathbf{0 , 7 8 7}$ & $-0,083$ \\
X13 & $\mathbf{0 , 8 1 6}$ & $-0,123$ \\
X21 & $\mathbf{0 , 8 4 0}$ & $-0,007$ \\
X22 & $\mathbf{0 , 8 2 0}$ & $-0,031$ \\
X23 & $\mathbf{0 , 8 6 4}$ & $-0,017$ \\
X31 & $\mathbf{0 , 7 8 9}$ & $-0,045$ \\
X32 & $\mathbf{0 , 8 2 4}$ & 0,036 \\
X33 & $\mathbf{0 , 8 6 2}$ & 0,009 \\
X41 & $\mathbf{0 , 8 5 9}$ & $-0,154$ \\
X42 & $\mathbf{0 , 8 6 0}$ & $-0,037$ \\
X43 & $\mathbf{0 , 8 7 5}$ & $-0,019$ \\
X51 & $\mathbf{0 , 8 1 0}$ & $-0,239$ \\
X52 & $\mathbf{0 , 0 0 8}$ & $\mathbf{0 , 8 8 6}$ \\
X53 & $\mathbf{0 , 7 9 7}$ & $-0,144$ \\
X61 & $\mathbf{0 , 8 6 5}$ & $-0,114$ \\
X62 & $\mathbf{0 , 7 9 7}$ & $-0,152$ \\
X63 & $-0,159$ \\
X71 & $\mathbf{0 , 7 5 4}$ & $-0,227$ \\
X72 & $\mathbf{0 , 8 4 0}$ & $-0,070$ \\
X73 & $\mathbf{0 , 8 4 8}$ \\
\hline
\end{tabular}




$\mid$\begin{tabular}{l|c|c|} 
X81 & $-0,102$ & $\mathbf{0 , 8 3 7}$ \\
X82 & $-0,072$ & $\mathbf{0 , 9 0 8}$ \\
X83 & $-0,063$ & $\mathbf{0 , 8 8 0}$ \\
X91 & $-0,096$ & $\mathbf{0 , 8 9 4}$ \\
X92 & $-0,062$ & $\mathbf{0 , 8 9 4}$ \\
X93 & $-0,106$ & $\mathbf{0 , 8 5 7}$ \\
\hline
\end{tabular}

After using factor rotation, the loading factor value is weighted. According to Ghozali (2008), the loading factor value more than 0.5 is considered strong enough to explain the construct. If there is a value below 0.5 then it must be removed. In Table 8, red means the variable is valid and strong enough to explain the factors. Thus to summerize variables X11 to X63 are valid for factor 1 and X71 to X93 are valid for factor 2.

\subsection{Renaming New Factor}

The results of factor rotation shows that the marketing mix and branding sub-variables are mixed in two different factors, thus it is necessary to give a new name or identity for each factor according to its characteristics (Widarjono, 2015). Furthermore, the results of the transformation of each component are displayed as follows.

Tabel 9. Factor transformation

\begin{tabular}{|c|c|c|}
\hline Component & I & II \\
\hline 1 & $\mathbf{0 . 9 5 2}$ & -0.307 \\
\hline 2 & 0.307 & $\mathbf{0 . 9 5 2}$ \\
\hline
\end{tabular}

Table 9 shows the correlation value from the transformation of components I and II is $0.952>0.500$ so that both components are feasible to summarize the 27 analyzed factors. Furthermore, the factors that shape consumer satisfaction UDS can be summarized as follows.

Tabel 10. Factor which forms UDS customer satisfaction.

\begin{tabular}{|c|c|c|c|c|}
\hline Factor & Code & Variabel Name & $\begin{array}{c}\text { Factor } \\
\text { Loading }\end{array}$ & Variance \\
\hline \multirow{8}{*}{$\begin{array}{c}\text { Factor } \\
\text { Tangible }\end{array}$} & $\mathrm{X} 11$ & Large Variation of Brand & 0,787 & \multirow{8}{*}{$48,116 \%$} \\
\hline & $\mathrm{X} 12$ & Expected product quality & 0,816 & \\
\hline & $\mathrm{X} 13$ & Large Variant of product offered & 0,840 & \\
\hline & $\mathrm{X} 21$ & Price suits its quality & 0,820 & \\
\hline & $\mathrm{X} 22$ & Price suits its benefit & 0,864 & \\
\hline & $\mathrm{X} 23$ & A competitive price offer & 0,789 & \\
\hline & $\mathrm{X} 31$ & $\begin{array}{l}\text { Location near to crowds (shopping } \\
\text { center, apartment, etc) }\end{array}$ & 0,824 & \\
\hline & X32 & Adequate facilities and & 0,862 & \\
\hline
\end{tabular}




\begin{tabular}{|c|c|c|c|c|}
\hline & & infrastructure & & \\
\hline & X33 & Accessible location & 0,859 & \\
\hline & $\mathrm{X} 41$ & Availability of discount & 0,860 & \\
\hline & $\mathrm{X} 42$ & $\begin{array}{l}\text { Availability of salesperson for } \\
\text { personal service }\end{array}$ & 0,875 & \\
\hline & $\mathrm{X} 43$ & Catalogue & 0,810 & \\
\hline & $\mathrm{X} 51$ & Employees active giving suggestion & 0,838 & \\
\hline & $\mathrm{X} 52$ & Polite Employees & 0,756 & \\
\hline & $\mathrm{X} 53$ & $\begin{array}{l}\text { Employees understand product } \\
\text { knowledge }\end{array}$ & 0,754 & \\
\hline & X61 & Availability of parking space & 0,840 & \\
\hline & X62 & Availability of delivery service & 0,865 & \\
\hline & X63 & Sufficient delivery vehicles & 0,797 & \\
\hline \multirow{9}{*}{$\begin{array}{c}\text { Factor } \\
\text { Intangible }\end{array}$} & $\mathrm{X} 71$ & Providing good service standard & 0,848 & \multirow{9}{*}{23,688} \\
\hline & $\mathrm{X} 72$ & $\begin{array}{l}\text { Providing good problem-solving } \\
\text { system }\end{array}$ & 0,886 & \\
\hline & $\mathrm{X} 73$ & Providing fast service procedure & 0,797 & \\
\hline & X81 & UDS Brand is well-known & 0,837 & \\
\hline & X82 & Positive assessment towards UDS & 0,908 & \\
\hline & $\mathrm{X} 83$ & Excited when shopping in UDS & 0,880 & \\
\hline & X91 & Customer are proud to shop in UDS & 0,894 & \\
\hline & X92 & Liking the transaction & 0,894 & \\
\hline & X93 & Comfortable transaction & 0,857 & \\
\hline
\end{tabular}

The variance value of the first factor $(48.116 \%)$ has a value greater than the second-factor variance $(23.688 \%)$. So the Tangible factor is the main forming factor of UDS customer satisfaction. While the second factor "Intangible" is a supporting factor that forms UDS customer satisfaction.

According to Lean W and B. Goodall (1966), the tangible aspect is the availability of tangible and quantifiable resources, the intangible aspect is the availability of intangible and quantifiable resources. UDS has several tangible and quantifiable aspects such as products sold and their prices, promotion, business locations, business environment and employees. Aspects that are intangible and cannot be calculated in UDS are brand image and also business processes such as problem-solving processes and product restocking processes. According to Puspita (2012), the tangible aspect is an aspect that can be felt by the human senses. For example, the service aspect cannot be seen, smelled, touched, and the way to assess service is by its tangible aspects, such as assessing the performance of friendly employees or the location of a comfortable waiting room. Intangible aspects according to Stewart (Steward, 2020), are commonly used in the operation of a business that does not have a physical form. 
These include the brand image, customer lists, patents, business processes, speciality skills, customer contracts, and licenses.

\section{Conclusions and Practical Implication}

Based on the results of the study, it can be concluded that from 27 variables used, 2 factors make up the satisfaction without any variables being discarded and Tangible factors are the main factors forming UDS consumer satisfaction with a variance of $48.116 \%$. The intangible factor is a supporting factor in shaping UDS customer satisfaction with a variance of $23.688 \%$.

Here below are suggestions for UDS managerial

Tabel 11. Managerial Impication Tangible Factor

\begin{tabular}{|c|c|}
\hline Factors & Strategy Implementation \\
\hline & $\begin{array}{l}\text { Brand variation of powder products, waterproofing, paint } \\
\text { cans, special dyes, adhesives, pipes, water fittings, } \\
\text { bathrooms, smoothing and grinding, drill bits and cutting } \\
\text { tools tobe expand at least into } 3 \text { brand variations }\end{array}$ \\
\hline & $\begin{array}{l}\text { The construction products, boards, hard fluids, machines, } \\
\text { selling meters, termites, doors and its accessories, electricity, } \\
\text { and hammer tools, should be expanded to at least } 2 \text { brand } \\
\text { variations. }\end{array}$ \\
\hline & $\begin{array}{l}\text { Products that have more functions should be added a } 10 \% \\
\text { profit margin from cost of goods sold. }\end{array}$ \\
\hline & Give clear directions \\
\hline & Provide both printed and digital catalogue. \\
\hline & $\begin{array}{l}\text { UDS Commissioner should provide training to its employees } \\
\text { on a regular basis on providing good service and actively } \\
\text { encourage the best product suggestions to customers. }\end{array}$ \\
\hline & $\begin{array}{l}\text { UDS should invest small vehicle such as a motorcycle with } \\
\text { cart in the back. }\end{array}$ \\
\hline & $\begin{array}{l}\text { UDS Should provide parking space in warehouse for } \\
\text { employee vehicles and provide cones at parking area }\end{array}$ \\
\hline
\end{tabular}

Tabel 12. Managerial Impication Intangible Factor

\begin{tabular}{|l|l|}
\hline \multirow{2}{*}{ Intangible } & $\begin{array}{l}\text { UDS must strive to maintain and improve in the future by } \\
\text { creating a computerized sales recording system and barcodes. } \\
\text { UDS Should train one of its senior employees to better } \\
\text { resolve problems and complaints from customers. }\end{array}$ \\
\cline { 2 - 3 } & $\begin{array}{l}\text { Expanding its marketing channels mainly through online, in } \\
\text { addition adding details of product knowledge in the UDS's } \\
\text { catalog. }\end{array}$ \\
\hline
\end{tabular}


Provide member card for UDS customers to increase their pride with various attractive promos or add online payment applications via Tokopedia or Shopee.

Suggestions for further research is to include more online marketplace elements in their research to keep in track on globalization, brand elements in this study are also limited, such as brand experience and brand attitude so in future research they can take other brand elements . In this study, intangible factors are supporting factors forming satisfaction. It is hoped that further research will conduct research in which intangible factors become the main forming factors so that research can be more refined.

\section{References}

Başer, İ. U., Cintamür, İ. G., \& Arslan, F. M. (2016). Examining the effect of brand experience on consumer satisfaction, brand trust and brand loyalty. İktisadi ve İdari Bilimler Dergisi, 37(2), 101-128. https://doi.org/10.14780/iibd.51125

Brakus, J. J., Schmitt, B. H., \& Zarantonello, L. (2009). Brand experience: what is it? How is it measured? Does it affect loyalty? Journal of Marketing, 73(3), 52-68.

Brazyte, K., Weber, F., \& Schaffner, D. (2017). Sustainability management of hotels: how do customers respond in online reviews? Journal of Quality Assurance in Hospitality $\backslash \&$ Tourism, 18(3), 282-307.

Carrizo-Moreira, A., Freitas-da Silva, P. M., \& Ferreira-Moutinho, V. M. (2017). The effects of brand experiences on quality, satisfaction and loyalty: an empirical study in the telecommunications multiple-play service market. Innovar, 27(64), 23-36.

Duy, P. N. N., \& Hoang, T. M. (2017). Factors Affecting Customer Satisfaction and Customer Loyalty the Case of Binh Duong Ceramic Product. Proceedings of NIDA International Business Conference 2017--Innovative Management: Bridging, 380.

Ghozali, I. (2008). Structural equation modeling: Metode alternatif dengan partial least square (pls). Badan Penerbit Universitas Diponegoro.

Hair, J. F., Sarstedt, M., Hopkins, L., \& Kuppelwieser, V. G. (2014). Partial least squares structural equation modeling (PLS-SEM): An emerging tool in business research. In European Business Review (Vol. 26, Issue 2, pp. 106-121). Emerald Group Publishing Ltd. https://doi.org/10.1108/EBR-10-2013-0128

Jr, J. F. H., Black, W. C., Babin, B. J., \& Anderson, R. E. (2010). Multivariate Data Analysis (Seventh Edition).

Keller, K. L. (1993). Conceptualizing, measuring, and managing customer-based brand equity. Journal of Marketing, 57(1), 1-22.

Kementerian PPN/Bappenas. (2018). Laporan kinerja kementerian PPN/Bappenas tahun 2018.

Khatab, J. J., Esmaeel, E. S., \& Othman, B. (2019). Dimensions of service marketing mix and its effects on customer satisfaction: a case study of international Kurdistan Bankin Erbil City-Iraq. TEST Engineering $\backslash \&$ Management, 4846, 4846-4855.

Ko, W.-H., \& Chiu, C. P. (2008). The relationships between brand attitude, customers' satisfaction and revisiting intentions of the university students--a case study of coffee chain stores in Taiwan. Journal of Foodservice Business Research, 11(1), 79-95.

Kotler, P., \& Armstrong, G. (2015). Principles of marketing-global edition. Pearson.

Lean, W., \& Goodall, B. (1966). Aspects of land economics. Bath: Ptmann Press. 
Lin, J. (2012). The factors affecting customer satisfaction and behavioral intentions in using mobile telecommunications service in Bangkok, Thailand. University of the Thai Chamber of Commerce.

Mills, C. W. (2000). The sociological imagination. Oxford University Press.

Nasrum, A. (2018). Uji normalitas data untuk penelitian. Jayapangus Press Books.

Puspita, R. N. (2012). Perbedaan kepuasan pelanggan Indomaret dan Alfamart. Journal of Social and Industrial Psychology, 1(1), 61-67.

Sabir, R. I., Ghafoor, O., Hafeez, I., Akhtar, N., \& Rehman, A. U. (2014). Factors affecting customers satisfaction in restaurants industry in Pakistan. International Review of Management and Business Research, 3(2), 869876.

Shafig, A.-H., Abeer, A.-A., Ibrahim, A.-H., \& Haddad, M. (2020). Factors affecting customers' satisfaction on buying residential apartments. Journal of Management Information and Decision Sciences, 23, 362-375.

Shin, N., Kim, H., Lim, S., \& Kim, C. (2014). The effect of brand equity on brand attitude and brand loyalty in exhibition. SHS Web of Conferences, 12, 1-7.

Steward, D. (2020). Defining And Building Intangible Assets | Branding Strategy Insider. https://www.brandingstrategyinsider.com/defining-and-building-intangible-assets/\#.YMmPCeAzbIU

Sugiono. (2014). Metode penelitian manajemen. Bandung: Alfabeta.

Tjiptono, F. (2019). Strategi pemasaran. Yogyakarta: Andi.

Tuan, V. K., \& Rajagopal, P. (2018). An investigation of factors affecting customers' satisfaction in the supermarket sector in Ho Chi Minh City (HCMC)-Vietnam. British Journal of Marketing Studies, 6(5), 42 61.

Widarjono, A. (2015). Analisis statistika multivariat terapan. Yogyakarta: UPP STIM YKPN.

World Bank. (2016). The World bank annual report 2016. In The World Bank Annual Report 2016. Washington, DC. https://openknowledge.worldbank.org/handle/10986/24985

Wu, S.-I., \& Lo, C.-L. (2009). The influence of core-brand attitude and consumer perception on purchase intention towards extended product. Asia Pacific Journal of Marketing and Logistics. 